\title{
Desviación de poder y prevaricación administrativa: diferencias y entrecruzamientos ${ }^{1}$
}

\author{
Mariano López Benítez (España) \\ Universidad de Córdoba \\ ad1lobem@uco.es
}

\begin{abstract}
NOTA BIOGRÁFICA
Doctor en Derecho por la Universidad de Córdoba con Premio Extraordinario. Catedrático de Derecho Administrativo de la Universidad de Córdoba. Como principales líneas de investigación desarrolla las siguientes: Administración y Derechos Fundamentales; Organización Administrativa; Derecho Administrativo económico; Derecho urbanístico; y Contratación Pública.
\end{abstract}

\section{RESUMEN}

Aunque en materia de invalidez de los actos administrativos, nuestras Leyes de Procedimiento Administrativo parecen partir de la existencia de unas nítidas diferencias entre la desviación de poder y la prevaricación administrativa, lo cierto es que las páginas de la jurisprudencia contencioso-administrativa rezuman interferencias y entrecruzamientos muy notables entre ambas categorías. En ocasiones, ello da lugar además a contradicciones muy patentes entre lo que declaran respectivamente las jurisdicciones penal y contencioso-administrativa. El propósito de este artículo pretende dar noticia sobre este problema y esbozar algunas soluciones al respecto.

\section{PALABRAS CLAVE}

Desviación de poder; prevaricación administrativa; invalidez de los actos administrativos.

\begin{abstract}
The Spanish laws on administrative procedures depart from a clear-cut distinction between misuse of power and administrative malfeasance for what regards the invalidity of administrative acts. Notwithstanding this, the case-law shows usual and important interferences and overlaps between the two categories, which results sometimes in blatant contradictions between the decisions of the administrative and the criminal courts. This article first explores this problem and then proceeds to sketch some proposals to solve it.
\end{abstract}

\section{KEYWORDS}

Misuse of power; administrative malfeasance; invalidity of administrative acts.

I. Continuando los paradigmas clásicamente consolidados por nuestras normas de procedimiento administrativo, la LPAC considera nulos de pleno derecho los actos de las Administraciones Públicas «que sean constitutivos de infracción penal o se dicten como consecuencia de ésta» [art. 47.1 d)], y estima, en cambio, anulables los actos de la Administración «que incurran en cualquier infracción del ordenamiento jurídico, incluso la desviación de poder» (art. 48.1). Aunque, en el plano práctico, pese a lo que un tanto apriorística-

\footnotetext{
1 Trabajo realizado en el marco del Proyecto de Investigación DER 2015-67695-C2-2-P, "Administración Pública y Derechos Fundamentales: nuevas perspectivas".
} 
mente se afirma, se da una notoria aproximación entre los efectos de la nulidad y la anulabilidad ${ }^{2}$, también es verdad que entre una y otra subsisten algunas diferencias importantes, como las relativas a la posibilidad de convalidar los actos anulables, o al carácter imprescriptible del plazo para el ejercicio de la acción de nulidad. Con tales matices y dejando al margen el supuesto de las irregularidades no invalidantes, existen, por tanto, dos regímenes de invalidez de los actos administrativos en nuestro ordenamiento jurídico. Dos regímenes -el de la nulidad y el de la anulabilidad- que el legislador parece haberlos entendido nítidamente diferenciados y sin posibles zonas de entrecruzamiento o de confusión, como prueba el hecho de que la primera se construya sobre supuestos de hecho cerrados mientras que la segunda se formule sobre presupuestos bastante más abiertos («cualquier infracción del ordenamiento jurídico»).

Sin embargo, en ocasiones, estas nítidas fronteras parecen difuminarse, ya que no hay que descartar que un acto que se dicte mediando desviación de poder encierre asimismo una conducta delictiva. No obstante, su suerte final, esto es, la de ser considerado como un acto administrativo nulo o anulable se hará depender en muchas ocasiones de los cauces procesales que, al respecto, se hayan seguido. En esta breve comunicación me fijaré en un aspecto concreto de este problema: en el contraste existente entre actos administrativos incursos en desviación de poder y actos administrativos cuyo dictado obedece a una prevaricación administrativa o aparezcan dictados a consecuencia de ésta.

II. Entre ambos tipos de actos inválidos, hay, en principio, una diferencia formal y competencial importante en orden a su declaración: la desviación de poder puede declararla el juez administrativo y entra, por tanto, plenamente dentro de sus facultades jurisdiccionales; en cambio, la prevaricación administrativa, por constituir un delito, sólo puede acordarla el juez penal ${ }^{3-4}$. Precisamente, este es uno de los expresos límites que el art. 3 a) LJCA pone al conocimiento del orden jurisdiccional contencioso-administrativo ${ }^{5}$. Las formas mediante las que puede llegarse a la declaración de este delito de prevaricación administrativa son variadas: en primer lugar, puede ocurrir que unas acciones u omisiones administrativas se residencien

2 Al respecto, véase REBOLLO PUIG, M. (2018): Derecho Administrativo. Régimen jurídico básico y control de la Administración (dir. por M. Rebollo Puig y D. Vera Jurado y coordinado por M. Rebollo Puig y E. Carbonell Porras), 3. ${ }^{a}$ ed., Madrid: Tecnos, págs. 110112. De particular interés a este respecto, es el documentado estudio de Tomás CANO CAMPOS que se incluye en este mismo número de Documentación Administrativa.

3 Aunque no es una cuestión pacífica, doctrinalmente se han formulado excepciones a este aserto. MORCILLO MORENO, J. (2007): Teoría y práctica de las cuestiones prejudiciales en el ámbito del Derecho Administrativo. Las posibles contradicciones entre resoluciones de distintos órdenes jurisdiccionales, Madrid: La Ley, plantea la siguiente cuestión: «....ante el advenimiento de ciertos acontecimientos de naturaleza imprevisible es posible que el proceso penal no pueda ya finalizar al devenir imposible su continuación. En tales supuestos, ¿cuál es la suerte que deberá correr la tramitación del procedimiento administrativo en orden a la declaración de nulidad de un acto administrativo constitutivo de infracción penal o dictado como consecuencia de ésta? ¿Deberá mantenerse la suspensión del mismo sine die -con la inherente consecuencia de mantener indefinidamente la ilegalidad de un acto administrativo ante la imposibilidad de que exista un pronunciamiento penal al respecto- o, por el contrario, podría admitirse que la propia Administración $y$, en su caso, los propios jueces administrativos de modo excepcional pudieran manifestarse acerca de la concurrencia de ilicitud en el acto en cuestión a los solos efectos de declarar su nulidad?» (pág. 482). A esta pregunta respondieron E. GARCÍA DE ENTERRÍA y T. R. FERNÁNDEZ, en el sentido de que «tal declaración puede ser imposible cuando el autor muera antes de dictarse la sentencia penal o sea inimputable o no sea habido, circunstancias todas ellas que no tienen porqué impedir las consecuencias estrictamente administrativas de su acción, si ésta es, en efecto, una acción antijurídica y está tipificada como delito en las Leyes penales» [vid. en la actualidad, Curso de Derecho Administrativo, I, 18. ${ }^{a}$ ed., Madrid: Thomson-Civitas, 2017, págs. 676 y 677$]$. Por ello, asumiendo esta posición, J. MORCILLO, op. cit. pág. 483, añade que «si el juez penal declarase en su resolución la concurrencia de alguna causa eximente, entendemos que no haría falta pronunciamiento prejudicial alguno por parte de la Administración o, en su caso, de la jurisdicción contencioso-administrativa desde el momento en que el juez penal, aunque exima de condena al presunto autor de la infracción, es lo cierto que sí puede hacer constar en la sentencia que el hecho constitutivo de la infracción penal y la participación en él del funcionario -y, por tanto, el que serviría para sustentar la declaración de nulidad con base en el artículo 62.1 d) Ley 30/1992- se produjo (ello al margen de la suerte penal que haya acompañado al sujeto en cuestión».

4 De gran interés es lo razonado por la SAP de Zaragoza, núm. 210/2015, de 31 de julio, rec. Apelación 133/2015, Ponente: Murillo y García Atance, ECLI: ES: APZ: 2015: 1707. Ante la alegación de las partes de que la jurisdicción penal no es competente para examinar el delito de prevaricación administrativa, la Audiencia sostiene que «debe ser desestimada totalmente. La jurisprudencia del Tribunal Supremo, a tal respecto, viene considerando que el delito de prevaricación no trata de sustituir a la jurisdicción contencioso-administrativa en su labor genérica de sometimiento de la actuación administrativa a la Ley y al Derecho, sino de sancionar supuestos-límite en los que la posición de superioridad que proporciona el ejercicio de la función pública se utiliza para imponer arbitrariamente el mero capricho de la autoridad o funcionario perjudicando al ciudadano afectado (o a los intereses generales de la Administración Pública) en un injustificado ejercicio de abuso de poder (SSTS 773/2014, 28/2010 y 259/2015). Interpuesta y admitida querella criminal por delitos de prevaricación no existe con carácter necesario una cuestión prejudicial administrativa, sino que de lo que se trata es de dilucidar si existió o no arbitrariedad o abuso de poder en la persona acusada y ello al margen de la actuación contencioso-administrativa que pueda tener lugar».

5 Justificado, como nos recuerda COSCULLUELA MONTANER, L. (2018): Manual de Derecho Administrativo, 29. ${ }^{a}$ ed., Madrid: Thomson-Civitas, pág. 578 en la preferencia de la jurisdicción penal sobre cualquier otra. 
autónoma y directamente ante el juez penal para que sea éste quien, a través del correspondiente proceso penal, determine si aquéllas constituyen o no delito de prevaricación administrativa. La conclusión del proceso penal y la sentencia condenatoria que, en su caso, en el seno del mismo se dicte, servirá, a su vez, de base para que posteriormente la Administración declare la nulidad del acto administrativo constitutivo de prevaricación o producido como consecuencia de ésta. Normalmente, el cauce empleado para ello será el de la revisión de oficio (art. 106.1 LPAC), no sólo por resultar muy probable que hayan transcurrido ya los plazos de caducidad existentes legalmente para la interposición de los recursos ordinarios por parte de los particulares, sino también muy fundamentalmente por el carácter obligado que el ejercicio de la potestad revocatoria tiene en estos casos para la Administración. Mas, junto a ello, no es infrecuente que el propio juez penal, a la vez que condena a una autoridad o funcionario por prevaricación, anule también el acto administrativo que ellos dictaron y que constituye el objeto mismo de la conducta delictiva. Estas últimas extensiones de la jurisdicción penal, objeto de una cierta comprensión por parte de la doctrina administrativista cuando se trata de actos administrativos en sí mismos constitutivos del delito de prevaricación, por entender que suponen «la aplicación de la legalidad administrativa en el marco de un proceso punitivo», merecen, en cambio, mayores reproches cuando el juez penal anula actos que son consecuencia de la prevaricación cometida, pero que ni han sido objeto de enjuiciamiento directo en el proceso penal, ni han ofrecido tampoco la posibilidad a los terceros afectados o beneficiados por dichos actos de ejercer sus facultades de defensa ${ }^{6}$.

Por otro lado, la declaración penal del delito de prevaricación administrativa puede producirse porque la intervención del juez penal se excite desde el proceso contencioso-administrativo en que se esté conociendo acerca de un acto o inactividad de la Administración. Surge así lo que procesalmente se conoce como cuestión prejudicial penal devolutiva. Sobre ella, la jurisprudencia contencioso-administrativa tiene establecido que la mera petición de plantear la suspensión por existir una cuestión prejudicial penal por parte de uno de los litigantes no impone al Juez o Tribunal contencioso-administrativo la necesaria suspensión de oficio del proceso contencioso-administrativo. Es necesario que éstos aprecien «indicios serios sobre hechos posiblemente delictivos y, además, de influencia decisiva sobre la cuestión principal debatida en el proceso contencioso-administrativo ${ }^{7}$. Por consiguiente, no siempre que exista prevaricación administrativa tiene porqué existir también causa de nulidad del acto administrativo, ya que, según la jurisprudencia

${ }^{6}$ Esta es la opinión conciliadora que, por ejemplo, expresa MUÑOZ MACHADO, S. (2015): Tratado de Derecho Administrativo y Derecho Público General, XII, 4. ${ }^{\text {a }}$ ed., Madrid: Boletín Oficial del Estado, p. 200: «El precepto que examinamos [art. 62.1 d) Ley 30/1992] diferencia entre los actos constitutivos de infracción penal y los dictados como consecuencia de la misma. Es más fácil que la sentencia penal pueda pronunciarse sobre la invalidez de los actos administrativos en el primer caso, en el que el acto correspondiente será necesariamente nulo por determinación del artículo 62.1 d) que ahora examinamos, de manera que la decisión sobre este extremo del tribunal penal solo supondrá la aplicación de la legalidad administrativa en el marco de un proceso punitivo, lo que no tiene nada de extraordinario sino que es absolutamente común (asuntos tributarios, medioambientales y urbanísticos, y otros muchos en los que los tipos penales se integran mediante remisiones a la legalidad administrativa), que en el caso de los actos dictados como consecuencia de una infracción penal. Estos últimos no tienen porqué ser necesariamente objeto de enjuiciamiento en el proceso penal, e incluso, pueden no llegar a ser conocidos por el tribunal que está enjuiciando el delito».

Por el contrario, GARCÍA DE ENTERRÍA, E. y FERNÁNDEZ, T. R. (2017): Curso de Derecho Administrativo, I, 18. a ed., Madrid: Thomson-Civitas, pág. 675, afirman que el art. 3 LECrim, «no extiende la competencia de los Tribunales penales a la declaración de nulidad de los actos administrativos implicados en el proceso penal, sino que limita expresamente el conocimiento y valoración de los mismos al solo efecto de represión, esto es, a efectos de la constatación del delito y de la imposición de la pena correspondiente, para llegar a las cuales es imprescindible el juicio previo de la legalidad de aquellos actos. Se perfila así con toda nitidez una solución distinta a la que venimos criticando, una solución que remite necesariamente a la incoación posterior a la sentencia penal y sobre la base de ésta de un procedimiento administrativo específicamente dirigido a la anulación de los actos administrativos prejudicialmente valorados por aquella sentencia, procedimiento en el que habrán de estar presentes como interesados necesarios los terceros a cuyo favor deriven derechos de aquellos actos (...) y en el que podrían y deberían modularse los efectos de la declaración de nulidad en los términos del artículo $110 »$.

7 STS de 2 de octubre de 2001, Sala 3. ${ }^{a}$, rec. cas. 4630/1997, Ponente: Maurandi Guillén: «A) La lectura de lo establecido en los arts 10.4 LOPJ y 4 LJCA no permite interpretar, como parece sostenerse por el recurrente de casación, que el mero planteamiento de una cuestión prejudicial penal, por uno de los litigantes, imponga al tribunal contencioso-administrativo la necesaria suspensión de oficio del proceso contencioso-administrativo, y aunque no conste la iniciación de un proceso penal.

A falta de esa iniciación, la suspensión de oficio requeriría, en su caso, para resultar justificada o procedente, que el tribunal contencioso-administrativo apreciara indicios serios sobre hechos posiblemente delictivos, y, además, de influencia decisiva sobre la cuestión principal debatida en el proceso contencioso-administrativo.

B) No consta que antes de dictarse la sentencia aquí recurrida de casación se hubiera acreditado ante la Sala "a quo" la iniciación de un proceso penal, y tampoco las actuaciones de instancia permiten apreciar esos indicios que resultarían inexcusables.

El contenido de ese polémico "Acuerdo de Gobierno" no revela una presión sobre la voluntad de alguno de los firmantes, ni tampoco la promesa de una entrega inequívocamente ilegal como contraprestación del apoyo político que en dicho pacto se conviene. 
contencioso-administrativa, es fundamental que «la resolución penal sea imprescindible para la del recurso contencioso-administrativo por existir una relación directa entre las cuestiones» ${ }^{8}$. La determinación de esta correspondencia directa entre los dos tipos de procesos es eminentemente casuística y tiene mucho que ver con las circunstancias concretas del caso y con los requisitos propios de la prevaricación administrativa ${ }^{9}$. Por otra parte, la exigencia de que exista esta relación directa y decisiva entre lo que determine la resolución penal y lo que deba decidir la jurisdicción contencioso-administrativa evita también que la mera invocación de una cuestión prejudicial penal se transforme en manos de las partes en una artimaña procesal dirigida

Lo que aparece es un proyecto de acción política sobre determinados problemas del municipio, aunque esté formulado en términos muy genéricos, y un compromiso de asignar determinadas funciones de gobierno municipal, pero este último tampoco presenta visos de necesaria ilegalidad.

C) El impulso procesal corresponde al órgano jurisdiccional, no a las partes litigantes (arts. 237 de la Ley Orgánica del Poder Judicial y 307 de la Ley de Enjuiciamiento Civil), por lo que estas últimas no pueden imponer a aquél el curso que ha de darse al proceso.

Por tanto, conferido traslado al Ayuntamiento para que formalizara la contestación a la demanda, este trámite debió realizarlo, y de esta obligación no le eximía ese planteamiento de cuestión prejudicial penal que formuló. La apreciación de la existencia o no de tal prejudicialidad es competencia exclusiva del Tribunal, y, por esta razón, el demandado debió prever el eventual fracaso de su planteamiento y presentar con carácter subsidiario la correspondiente contestación. Y si no lo hizo así sólo a él le son imputables las consecuencias de su inactividad».

8 STS 13 de septiembre de 2002, Sala 3. a, rec. cas. 2347/1998, Ponente: Martín González: «Ha de destacarse, en primer término, que tal cuestión de suspensión o paralización del proceso contencioso-administrativo por razón de la existencia de un procedimiento penal por prevaricación y tráfico de influencias ante un Juzgado de Instrucción contra determinados concejales, fue contundentemente resuelta, con argumentos exhaustivos, por cierto, en el Auto de la Sala de Instancia de 8 de enero de 1998 en el sentido de que no procedía la suspensión del proceso contencioso-administrativo, contra la que, también por cierto, cabía recurso de súplica, que no se interpuso, pese a que consta notificado y a que su contenido fue bien conocido -o pudo serlo- por la parte que ahora, en casación, parece oponerse a él, de modo que, a efectos de este recurso de casación, bien cabe entender que obtuvo firmeza y que, en definitiva la no suspensión o paralización del proceso contencioso-administrativo es una decisión que ahora resultaría inobjetable, en principio, mas, para agotar la cuestión, cabe invocar también que, a tenor de los arts. 4.1 de la Ley de esta Jurisdicción y 10.2 de la Ley Orgánica del Poder Judicial, que ciertamente exceptúan la excepción de la competencia del orden jurisdiccional contencioso-administrativo para el conocimiento y decisión de las cuestiones prejudiciales de carácter penal (en términos equivalentes a los de los arts. 362 de la Ley de Enjuiciamiento Civil y 114 de la de Enjuiciamiento Criminal), lo que resulta de aquéllos no es ni puede ser nunca cobijo de una artimaña procesal frecuente consistente en promover una querella penal para obtener una suspensión deseada, puesto que sólo habrá lugar a esta suspensión o paralización del recurso contencioso-administrativo cuando la causa penal ostente tal relieve que, sin su previo conocimiento y decisión en el ámbito del proceso penal, resulte imposible decidir sobre lo planteado en el recurso contencioso-administrativo -o, dicho de otro modo- cuando la resolución penal sea imprescindible para la del recurso contencioso-administrativo, por existir una directa relación entre las cuestiones, lo que aquí obviamente no sucede, sea cual sea el resultado de la causa penal, puesto que lo que se halla en juego son aspectos que, relacionados con el Decreto impugnado, implican o pueden implicar violación de fundamentales derechos, al privarse a unos Concejales de la posibilidad de debatir y de votar en una moción de censura, que es lo que, juntamente, se ventila en el proceso contencioso-administrativo, como explica con acierto la Sala de Instancia en el Auto de 8 de enero de 1998 con argumentos que esta Sala comparte, y cuando el objeto de la cuestión penal no incide en el ámbito de este recurso, lo que impone la desestimación de tal primer motivo de la casación».

9 Paradigma de lo que se dice podría ser el caso contemplado por la STSJ Galicia, núm. 733/2014, de 10 de diciembre, Sala de lo Contencioso, rec. Apelación 240/2014, Ponente: Chaves García, ECLI: ES: TSJGAL: 2014: 8604. El Auto del Juzgado de lo Contencioso-Administrativo núm. 2 de Pontevedra, de 31 de marzo de 2014 había acordado la suspensión del proceso seguido ante él, por existir una cuestión prejudicial penal (en concreto, existian unas diligencias previas ante el Juzgado de Instrucción núm 2 de los de Pontevedra). El acto administrativo del que conocía el Juzgado de lo Contencioso era la Resolución de 23 de octubre de 2012, confirmada en alzada, por la que se elevaban a definitivas las puntuaciones otorgadas a los aspirantes presentados a la convocatoria para la provisión del puesto de Jefe del servicio de Psiquiatría de un determinado complejo hospitalario. La Administración recurre el Auto del Juzgado de lo Contencioso, por estimar improcedente el planteamiento de la cuestión prejudicial. Argumento que el TSJ rechaza en los siguientes términos: «...la cuestión prejudicial requiere la mera influencia decisiva de la cuestión penal sobre la contencioso-administrativa hasta el punto que el legislador ha otorgado prevalencia y prioridad a esa valoración efectuada en la causa penal, lo que resulta especialmente patente en el caso ahora analizado puesto que la demanda contencioso-administrativa gira en torno a un posible plan preconcebido para sortear los principios de mérito y capacidad, constando la denuncia por comisión de delitos de prevaricación, tráfico de influencias y falsedad documental frente al Gerente del Complejo Hospitalario [...] y los miembros de la Comisión de Evaluación de los méritos de los dos candidatos a la plaza de Jefe del Servicio de Psiquiatría [...] turnada al Juzgado de Instrucción núm 2 [...] es clara la conexión e incidencia directa de las actuaciones penales con la actuación administrativa impugnada [...] En el caso que nos ocupa, el núcleo de la decisión administrativa cuestionada (adjudicación de plaza de Jefe de Servicio), se vincula a dos actuaciones administrativas que están teñidas de discrecionalidad, o sea, se amparan en una potestad con amplio margen de libertad y confianza en el recto criterio de quien la usa (en particular el diseño o impulso de la convocatoria y su concreta aplicación por la Comisión al valorar los aspirantes) de manera que el ataque penal sobre la posible parcialidad y predeterminación de la actuación impugnada sobre la posible parcialidad y predeterminación de la actuación impugnada por posible prevaricación, tráfico de influencias o falsedad reviste influencia directa pues su apreciación o estimación penal comportaría no solo la nulidad de la actuación administrativa por fuerza del art. 61, apartado d) de la Ley 30/1992, de 26 de noviembre,, sino que privaría de toda legitimidad a la potestad discrecional que desembocó en la actuación impugnada, además de desvelar la existencia de motivos de abstención (...) y encerrar el vicio de la desviación de poder. Asimismo, hacemos notar que la base de la suspensión del litigio es la existencia de un escenario fáctico común, sin que resulte admisible que unos mismos hechos puedan existir y no existir según la jurisdicción que los enjuicie». 
a suspender y paralizar el proceso contencioso-administrativo ${ }^{10}$. Evidentemente, la determinación de si la decisión penal tiene o no una influencia decisiva en el proceso contencioso-administrativo es una decisión que compete al juez contencioso-administrativo, y que presenta un alto grado de discrecionalidad ${ }^{11}$

III. Advertida esa influencia decisiva entre la resolución penal y la contencioso-administrativa, y a falta de una regulación propia en la LJCA, el régimen jurídico de la cuestión prejudicial penal se atiene a lo previsto en los arts. 40 y 41 LEC $^{12}$. En virtud del apartado $2 .^{\circ}$ del primero de estos preceptos la suspensión de las actuaciones contencioso-administrativas se condiciona, por una parte, a que se acredite la existencia de causa criminal en la que se estén investigando, como hechos de apariencia delictiva, alguno o algunos de los que fundamenten las pretensiones de las partes en el proceso contencioso-administrativo; y, por otra parte, según ya hemos anticipado, a que la decisión del tribunal penal acerca del hecho por el que se procede en causa criminal pueda tener influencia decisiva en la resolución sobre el asunto contencioso-administrativo ${ }^{13}$.

Además, la existencia de una cuestión prejudicial no determina por sí sola y desde el mismo instante en que se aprecia, la suspensión del proceso contencioso-administrativo, la cual «se acordará, mediante auto, una vez que el proceso esté pendiente sólo de sentencia» (art. 40.3 LEC), extendiéndose esta suspensión hasta que se acredite que el juicio criminal haya terminado o que se encuentra paralizado por motivo que haya impedido su normal continuación (art. 40.6 LEC) ${ }^{14}$. Sólo para los casos en que la suspensión venga motivada por la posible existencia de un delito de falsedad de alguno de los documentos aportados, la suspensión «se acordará, sin esperar a la conclusión del procedimiento, tan pronto como se acredite que se sigue causa criminal sobre aquel delito, cuando, a juicio del tribunal, el documento pudiera ser decisivo para resolver sobre el fondo del asunto» (art. 40.4 LEC).

IV. Junto a los dos vías indicadas, habría también un tercer camino para que el juez penal aprecie la concurrencia, en su caso, de un delito de prevaricación administrativa. Consiste esta posibilidad en que, con posterioridad a la anulación de un acto en vía contencioso-administrativa, se lleve la actuación administrativa ante la jurisdicción penal con vistas a que ésta declare la existencia de responsabilidad penal para con respecto a los autores del acto administrativo anulado. La procedencia de esta vía requiere algunas matizaciones. La primera y más evidente es que no toda anulación de un acto administrativo permite sin más al juez penal estimar que existe prevaricación ${ }^{15}$. Para ello, es preciso que se den los requisitos propios de la prevaricación administrativa y, de entre ellos, es necesario que se de un verdadero «torcimiento del derecho» y no cualquie-

10 De «artimaña procesal» se habla precisamente en el fundamento transcrito en nota anterior de la STS de 13 de septiembre de 2002 .

11 Con gran claridad lo expresa MORCILLO MORENO, J. (2007): Teoría y práctica..., pág. 290, quien señala además los límites de tal discrecionalidad: «con todo, la apreciación de la existencia o no de prejudicialidad es algo discrecional por parte del juez, sin que a ello obste la existencia de recursos contra la decisión que aquél adopte. Así, suscitada una cuestión penal en el seno de un proceso contencioso-administrativo, al juez administrativo corresponde únicamente, en uso de una facultad discrecional, determinar si tal cuestión de naturaleza penal reúne o no los requisitos que la convierten en prejudicial respecto al objeto principal del proceso administrativo; pero, constatado el vínculo prejudicial, finaliza la discrecionalidad del juez administrativo dejando paso a la obligación de éste de suspender, llegado el momento procesal oporuno, el proceso administrativo para la correcta resolución de la cuestión prejudicial por el juez penal».

12 Sobre esta supletoriedad, véase SANTAMARÍA PASTOR, J. A. (2010): "Comentario al art. 4", en La Ley Reguladora de la Jurisdicción Contencioso-Administrativa. Comentario, Madrid: lustel, págs. 114-119.

13 Como relata MORCILLO, J. (2007): Teoría y práctica..., págs. 291-293 y nota 282, en virtud de lo prevenido en el art. 40.1 LEC, el planteamiento de la cuestión prejudicial puede hacerse de oficio por el juez administrativo, poniendo -mediante providencia- los hechos presumiblemente delictivos en conocimiento del Ministerio Fiscal. Éste emitirá dictamen al respecto, «no tanto sobre existencia de la cuestión prejudicial -pues tal extremo corresponde de un modo discrecional al juez-, cuanto sobre la procedencia o no de la formación de la causa penal». A la vista del dictamen, el juez contencioso-administrativo instará del juez penal la incoación del proceso penal, «tras, cuya acreditación podrá el juez, en el momento procesal oportuno, acordar la suspensión del proceso principal».

14 Aunque referida al derogado art. 362 LEC, hay una buena exposición de las posiciones jurisprudenciales seguidas con respecto a los momentos para el planteamiento de la cuestión prejudicial penal en la STSJ Islas Canarias 569/2004, de 21 de julio, Sala de lo Contencioso-Administrativo, rec. 726/2001, Ponente: Suárez Tejera.

15 Como dice la SAP de Cantabria, núm. 12/2004, de 28 de mayo, proc. Abreviado 8/1997, Ponente: De la Hoz de la Escalera, «no hay duda de que aquel acto administrativo, decisorio y positivo y apto en principio para ser base de un delito de prevaricación, no era ajustado a Derecho, pero tal realidad jurídica actualmente conocida no es bastante para poder afirmar la perpetración del delito, pues, como queda dicho, es preciso constatar además de forma indudable que la resolución es injusta, arbitraria en notoria e incuestionable contradicción con el ordenamiento jurídico, que suponga, como indican muchas sentencias del TS, entre ellas, la de 25 de septiembre de 2001, un verdadero torcimiento del Derecho».

En el supuesto contemplado por la sentencia parcialmente transcrita, el Tribunal Contencioso-Administrativo había anulado el acto, puesto que los funcionarios municipales no podían paralizar unas obras de Red Eléctrica porque la competencia era estatal. Sin 
ra otra ilegalidad administrativa ${ }^{16}$. Por tanto, la posición del juez penal resulta aquí completamente autónoma e independiente con respecto a lo que haya podido decir al respecto la jurisdicción contencioso-administrativa cuando anuló el acto. Tal autosuficiencia del juez penal es además trasunto de la posición que, en general, ostenta a la hora de plantear o no una prejudicialidad administrativa con arreglo a lo dispuesto en los arts. 3 y 4 LECrim. En este sentido, la jurisprudencia penal se muestra extraordinariamente cicatera a la hora de admitir que el juez penal plantee una prejudicialidad administrativa que le ayude a apreciar si se dan o no los elementos de la prevaricación administrativa o de cualquier otro delito ${ }^{17}$ : como regla, la jurisprudencia penal sostiene que el juez penal, por sí mismo y sin plantear prejudicial administrativa alguna, debe condenar o sobreseer, según aprecie o no con plena autonomía la concurrencia de los requisitos del delito de prevaricación ${ }^{18}$. Con rotundidad lo expresa, por ejemplo, la SAP de Sevilla 193/2000, de 18 de septiembre ${ }^{19}$.

Mas, junto a la matización indicada, cabe formular otra segunda. La anulación del acto en vía contencioso-administrativa ha podido destapar y poner de relieve los elementos suficientes para que pudiera entablarse posteriormente una acción penal contra la autoridad o el funcionario que dictaron el acto anulado por entender que en su dictado hubiese podido mediar un delito de prevaricación administrativa. En tales casos,

embargo, desde el punto de vista hermenéutico, la cuestión competencial era tan compleja que la valoración e interpretación realizadas por los funcionarios «no era en absoluto irrazonable, absurda y sin sentido».

16 SAP 12/2004, de 28 de mayo.

17 MUÑOZ MACHADO, S. (2015): Tratado..., pág. 199, dice que «la autosuficiencia de la jurisdicción penal se ha exacerbado hasta el extremo de que solicitar de ella la suspensión del procedimiento para que otra jurisdicción resuelva previamente cualquier extremo jurídicamente conflictivo sería un desconocimiento de sus comportamientos habituales verdaderamente ingenuo». Esta libertad sólo encontraba una excepción con respecto a los delitos de intrusismo profesional, ya que durante una época la jurisprudencia constitucional estimaba los recursos de amparo interpuestos contra sentencias condenatorias por considerar vulnerado el derecho a la tutela judicial efectiva (SSTC 30/1996, 50/1996, 91/1996, 102/1996 y 255/2000), al apreciar contradicción entre la jurisdicción penal y la contenciosoadministrativa sobre la validez del título empleado para el ejercicio de la profesión, lo que en la práctica se traducía en que el juez penal se veía obligado a plantear una prejudicial administrativa devolutiva para que la jurisdicción contencioso-administrativa se pronunciase sobre la validez administrativa del título profesional [cfr. GARCÍA DE ENTERRÍA, E. y FERNÁNDEZ, T. R. (2017): Curso de Derecho Administrativo, II, 15. ${ }^{a}$ ed., Madrid: Thomson-Civitas, pág. 632]. Sin embargo, tal doctrina constitucional se vio enormemente matizada, como explica la STS, núm. 1490/2001, de 24 de julio, Sala 2. ${ }^{a}$, rec. cas. 3204/1999, Ponente: Conde-Pumpido Tourón, a partir de la STC 278/2000, de 27 de noviembre, que desestimó el recurso de amparo interpuesto contra una condena por delitos de estafa y falso testimonio, fundado en la supuesta obligatoriedad del planteamiento previo de una cuestión prejudicial devolutiva de naturaleza civil, de la que dependía la concurrencia de un elemento básico del tipo delictivo de estafa. En esta resolución, como explica el TS, se destaca acertadamente que «normalmente carece de relevancia constitucional la posibilidad de que puedan producirse resultados contradictorios entre órganos judiciales de distintos órdenes, cuando la contradicción es consecuencia de los distintos criterios informadores del reparto de competencia que ha llevado a cabo el legislador».

Añadiendo el Tribunal Constitucional, con carácter general, que «en los asuntos que hemos denominado complejos (es decir, en aquellos en los que se entrelazan instituciones integradas en sectores del ordenamiento cuyo conocimiento ha sido legalmente atribuido a órdenes jurisdiccionales diversos), es legítimo el instituto de la prejudicialidad no devolutiva, cuando el asunto resulte instrumental para resolver la pretensión concretamente ejercitada y a los solos efectos de ese proceso, porque no existe norma legal alguna que establezca la necesidad de deferir a un orden jurisdiccional concreto el conocimiento de una cuestión prejudicial y corresponde a cada uno de ellos decidir si se cumplen o no los requerimientos precisos para poder resolver la cuestión, sin necesidad de suspender el curso de las actuaciones, siempre y cuando la cuestión no esté resuelta en el orden jurisdiccional genuinamente competente».

Es decir que el propio Tribunal Constitucional admite: a) que no existe norma legal alguna que establezca la necesidad de deferir a un orden jurisdiccional concreto el conocimiento de una cuestión prejudicial; b), que corresponde a cada uno de ellos decidir si se cumplen o no los requerimientos precisos para poder resolver la cuestión, sin necesidad de suspender el curso de las actuaciones; c) que a lo que está obligado el Tribunal penal es a respetar el pronunciamiento previo del orden jurisdiccional genuinamente competente, cuando la cuestión ya esté resuelta por éste.

Concluyendo el Tribunal Constitucional en dicha resolución (STC 278/2000, de 27 de noviembre, fundamento jurídico séptimo, «in fine») que cuando el Tribunal penal analiza el hecho desde la óptica que le corresponde y a los solos efectos de la determinación de uno de los elementos del tipo penal, con ello no puede integrar la vulneración del derecho a la tutela judicial efectiva que proclama el art. 24.1 de la Constitución Española».

18 Críticamente contra esta autosuficiencia de la jurisdicción penal y lo que ella puede implicar en relación con el derecho a la tutela judicial efectiva, MORCILLO, J. (2007): Teoría y práctica..., cit., págs. 487-489.

19 SAP de Sevilla, núm. 193/2000, de 18 de septiembre, rec. apelación 4369/2000, Ponente: De Paúl Velasco: «...como bien apunta la Magistrada "a quo", la configuración del delito de prevaricación determina que si puede existir alguna duda razonable acerca de la conformidad a Derecho de la resolución dictada que deba ser dirimida por el orden jurisdiccional contencioso-administrativo tal situación de auténtica prejudicialidad deberá acarrear, no la suspensión del proceso penal, sino su conclusión por auto de sobreseimiento o sentencia absolutoria, al estar ausente el decisivo elemento típico de arbitrariedad de la resolución; mientras que, por el contrario, cuando dicha arbitrariedad sea apreciable con la seguridad exigible en vía penal, por ello mismo no será precisa la previa decisión del orden contencioso-administrativo sobre la legalidad o ilegalidad de la resolución para determinar la culpabilidad o inocencia del imputado, y el órgano judicial penal podrá pronunciarse al respecto, conforme a los artículos 3 de la Ley de Enjuiciamiento y 10 de la Ley Orgánica del Poder Judicial, adquiriendo entonces la pretendida prejudicialidad devolutiva el carácter de un mero efugio tendente a retardar la acción de la justicia penal o a vaciar materialmente de competencia a sus órganos. En el primer sentido expuesto puede citarse la sentencia del Tribunal Supremo de 5 de julio de 1994 , y en el segundo la de 20 de enero de $1996 »$. 
es evidente que la sentencia condenatoria penal carecerá de trascendencia alguna con respecto a la sentencia contencioso-administrativa que anuló ya el acto administrativo objeto de la prevaricación, sentencia que se encontrará pertrechada por los efectos de la cosa juzgada y que, in extremis, sólo podría ser objeto de un recurso extraordinario de revisión si se dan los presupuestos exigibles para su planteamiento.

V. Los problemas que se suscitan en todos estos casos es que la anulación del acto administrativo por parte de la jurisdicción contencioso-administrativo ha podido producirse por una causa que no es de estricta nulidad, sino de anulabilidad. Con independencia de que, como anticipamos, en la práctica los efectos de una y otra hayan terminado por aproximarse, lo cierto es que el acto administrativo ha podido ser anulado por desviación de poder y, sin embargo, haya servido para desvelar ahora elementos que conformen una condena penal por prevaricación administrativa. No es infrecuente en este sentido encontrarnos con sentencias del orden contencioso-administrativo que, anulando el acto por desviación de poder, dejan caer como obiter dicta la posibilidad de que el acto administrativo pudiera ser, a su vez, expresión de una prevaricación administrativa. No obstante, si el razonamiento no pasa de ahí, esto es, si ni los demandantes ni el juez contencioso-administrativo excitaron la intervención de la jurisdicción penal mediante el pertinente planteamiento de la cuestión prejudicial penal, el mismo acto terminará siendo visto de dos formas diferentes según cuál sea la jurisdicción que lo observe: para el orden contencioso-administrativo será un acto incurso en desviación de poder y para el juez penal, en cambio, el dictado de dicho acto obedecerá y servirá de base para condenar por la comisión de un delito de prevaricación administrativa. Una distinta mirada que tendrá mucho que ver con el celo que se haya mostrado en la vía contencioso-administrativa a la hora de desentrañar si el acto objeto del recurso presentaba indicios suficientes para determinar que su dictado encerraba la realización de un delito de prevaricación administrativa ${ }^{20}$

VI. Ante esta situación, la cuestión que inmediatamente aflora es la siguiente: ¿desviación de poder y prevaricación administrativa pueden devenir en algunos casos categorías intercambiables? ¿existen diferencias conceptuales nítidas entre una y otra? Las interrogantes planteadas son importantes, puesto que, como ya dijimos, la LPAC parece partir de la premisa de que las diferencias entre desviación de poder y prevaricación son claras, reservando, por tanto, distintas consecuencias jurídicas para los actos administrativos según estén inmersos en prevaricación administrativa o se hallen afectados por desviación de poder.

En lo que concierne a la desviación de poder, tanto la doctrina como la jurisprudencia administrativa tienen trazadas unas líneas conceptuales claras. Para nuestra jurisprudencia contencioso-administrativa, la desviación de poder implica, como se sabe, los siguientes requisitos:

a) En la desviación de poder se incurre tanto si se persigue un fin público como un fin privado, ya que, como nos recuerda el art. 70.2 LJCA, lo relevante es que se ejercite una potestad administrativa para un fin distinto del fijado por el ordenamiento jurídico para dicha potestad.

b) Aunque se produzca con mayor frecuencia en el ejercicio de potestades discrecionales, en principio nada obsta a que se dé también con ocasión del ejercicio de potestades regladas.

c) Puede concurrir con otros vicios del acto o constituir, por el contrario, el único vicio que el acto administrativo presente; sin embargo, en el primer caso, aquellos otros vicios de invalidez deben ser examinados antes que el de la desviación de poder.

d) Probar la desviación de poder es una carga que incumbe a quien la alega.

e) Por último, como probar plenamente la desviación de poder no es tarea fácil, la jurisprudencia contencioso-administrativa admite los indicios y las presunciones como medios de prueba, siempre que el empleo de éstos lleven al juez a la razonable convicción de que en el acto administrativo objeto de control existe una desviación de poder ${ }^{21}$.

20 En cualquier caso, no hay que perder de vista lo que dispone el art. 40.1 LEC, cuya supletoriedad con respecto a la LJCA ya ha quedado destacada más atrás: "Cuando en un proceso civil se ponga de manifiesto un hecho que ofrezca apariencia de delito o falta perseguible de oficio, el tribunal civil, mediante providencia, lo pondrá en conocimiento del Ministerio Fiscal, por si hubiere lugar al ejercicio de la acción penal».

21 A los requisitos indicados en el texto, que son los que más asiduamente se citan como doctrina jurisprudencial, MUÑOZ MACHADO, S. (2015): Tratado de Derecho Administrativo y Derecho Público General, III, 4. ${ }^{a}$ ed., Madrid: BOE, pág. 280 añade, con base en las SSTS de 5 de octubre de 1983 y de 3 de febrero de 1984, la posibilidad de que la desviación de poder pueda consistir «tanto en un hacer activo como en la deliberada pasividad cuando concurre en el órgano administrativo competente una obligación específica de actuación positiva». 
Por otro lado, en lo que respecta al delito de prevaricación administrativa, regulado en el art. $404 \mathrm{CP}^{22}$, la jurisprudencia penal también tiene sentados unos rasgos muy nítidos.

a) Tanto el concepto de funcionario como el de autoridad pública se interpretan en un sentido amplio, comprensivo de cualquier forma de participación en el ejercicio de funciones públicas, independientemente de cuál sea el modo de elección o selección de este personal; su forma de retribución; la naturaleza estatutaria o laboral de la relación jurídica que lo vincule con la Administración, o el carácter permanente o temporal de dicha relación ${ }^{23}$.

b) La jurisprudencia penal relaciona el concepto de resolución administrativa con toda aquella resolución -dictada en asunto competencia de la Administración- que posea en sí misma un efecto ejecutivo, esto es, que decida sobre el fondo del tema sometido a juicio de la Administración ${ }^{24}$. Tal conceptuación excluye, en principio, los denominados actos políticos del Gobierno, así como la gran mayoría de los actos de trámite que se vierten durante el procedimiento administrativo. De todos modos, hay que recordar que para determinados actos de trámite, como los informes, el CP prevé la existencia de tipos específicos ${ }^{25}$

c) Asimismo, pese a sus iniciales reticencias al respecto ${ }^{26}$, la jurisprudencia penal ha terminado por admitir la comisión por omisión del delito de prevaricación administrativa para aquellos casos es-

Asimismo, precisa que la jurisprudencia del Tribunal Supremo acepta también que la desviación de poder «pueda producirse con ocasión del ejercicio de potestades no decisorias, sino puramente procedimentales o de trámite» [op. cit. pág. 282]

22 Dice este precepto: «A la autoridad o funcionario público que, a sabiendas de su injusticia, dictare una resolución arbitraria en un asunto administrativo, se le castigará con la pena de inhabilitación especial para empleo o cargo público y para el ejercicio del derecho de sufragio pasivo por tiempo de nueve a quince años».

${ }_{23}$ Hay que recordar que, junto al autor del delito de prevaricación -que tiene que ser siempre una autoridad o funcionario público en ese sentido lato que se expresa en el texto-, la jurisprudencia admite la figura del extraneus como inductor o cooperador. En este sentido, para que un extraneus pueda devenir inductor, es preciso, según la jurisprudencia penal, que: a) la inducción se ejerza sobre alguien que no está resuelto a delinquir previamente; b) la incitación sea intensa y adecuada; c) se induzca a la comisión de un delito determinado y a un autor concreto; y d) el inducido realice el delito. Por otra parte, para que un extraneus pueda ser considerado cooperador de un delito de prevaricación administrativo es necesario que: a) se colabore con el ejecutor directo aportando una conducta sin la cual el delito no se habría cometido (teoría de la condictio sine qua non); b) se colabora mediante la aportación de algo que no es fácil de obtener de otro modo (teoría de los bienes escasos); y c) cuando el que colabora puede impedir la comisión del delito retirando su concurso (teoría del dominio de hecho). A todo ello, como afirma la SAP de Málaga, núm. 17/2017, de 20 de enero, proc. 10/2012, Ponente: Criado Gómez, «habría que añadir que debe concurrir en el partícipe extraneus el elemento intencional del tipo, en este caso, la colaboración para el dictado de una resolución injusta y arbitraria».

${ }_{24}$ Como dice la SAP de Asturias, núm. 271/1998, de 21 de mayo, proc. Abreviado 40/1996, Ponente: Donapetry Camacho: «no es solo el acto administrativo realizado por escrito que recibe tal denominación expresa, sino también todo acto positivo (...) generalmente escrito, pero también puede ser verbal (STS 7 de noviembre de 1986), dictado o realizado, o que debería dictarse o realizarse en un expediente administrativo en el que se resuelve o se decide algo (que no sea repetición de algo anterior o pura ejecución de una resolución superior), algo que tiene repercusión para otros o produce efectos para otras personas (pues un acto inocuo sin ninguna trascendencia para otros carece de relevancia jurídica».

25 De todos modos, hay que reconocer con GONZÁLEZ CUSSAC, J. L. (1997): El delito de prevaricación de autoridades y funcionarios públicos, 2. ${ }^{a}$ ed., Valencia: Tirant lo Blanch, pág. 96, que si el acto de trámite posee carácter decisorio entraría claramente dentro del tipo. Por lo demás, como se dice en el texto, en relación con los informes se prevén tipos específicos en materia de ordenación territorial y urbanismo: "La autoridad o funcionario público que, a sabiendas de su injusticia, haya informado favorablemente instrumentos de planeamiento, proyectos de urbanización, parcelación, reparcelación, construcción o edificación o la concesión de licencias contrarias a las normas de ordenación territorial o urbanísticas vigentes, o que con motivo de inspecciones haya silenciado la infracción de dichas normas o que haya omitido la realización de inspecciones de carácter obligatorio será castigado con la pena establecida en el art. 404 de este Código, y, además, con la de prisión de un año y seis meses a cuatro años y la de multa de doce a veinticuatro meses» (art. 320.1). También en materia de patrimonio histórico: "La autoridad o funcionario público que, a sabiendas de su injusticia, haya informado favorablemente proyectos de derribo o alteración de edificios singularmente protegidos será castigado además de con la pena establecida en el artículo 404 de este Código con la de prisión de seis meses a dos años o la de multa de doce a veinticuatro meses» (art. 322.1). Finalmente, asimismo se contempla un tipo penal específico en materia de industria: «La autoridad o funcionario pública que, a sabiendas, hubiere informado favorablemente la concesión de licencias manifiestamente ilegales que autoricen el funcionamiento de las industrias o actividades contaminantes a que se refieren los artículos anteriores, o que con motivo de sus inspecciones hubiere silenciado la infracción de leyes o disposiciones normativas de carácter general que las regulen, o que hubiere omitido la realización de inspecciones de carácter obligatorio, será castigado con la pena establecida en el artículo 404 de este Código y, además, con la de prisión de seis meses a tres años y la de multa de ocho a veinticuatro meses».

Además de lo expuesto, sí podría castigarse como prevaricación administrativa la falta de informes o trámites preceptivos, pues, como señala GONZÁLEZ CUSSAC, J. L. (1997): op. cit., pág. 90, «no se trata de un comportamiento omisivo, sino claramente positivo o activo, pues sí se dicta una resolución expresa, eso sí, omitiendo exigencias procedimentales básicas. Y justamente su ausencia convierte a la resolución en arbitraria».

${ }^{26}$ Este «giro jurisprudencial» del que da noticia la STS de 27 de diciembre de 1995, Sala 2. a, Rec. 36/95, Ponente: Bacigalupo Zapater, fue finalmente reconocido por el Acuerdo no jurisdiccional de la Sala de lo Penal del TS de 30 de junio de 1997. Aunque en esta breve colaboración no podamos entrar con profundidad en el tema, hay que recordar que este Acuerdo vino fundamentalmente moti- 
peciales en los que es imperativo para el funcionario dictar la resolución y la omisión tiene efectos equivalentes a una denegación (STS de 27 de diciembre de 1995), o «bien porque exista una norma que de forma imperativa imponga la adopción de una resolución y la Administración haya realizado alguna actuación tras la cual sea preciso legalmente dictar una resolución, de manera que la omisión de la misma equivalga a una resolución denegatoria, implicando de alguna manera un reconocimiento o denegación de derechos» (ATS de 10 de abril de 2018) ${ }^{27}$.

d) El art. $404 \mathrm{CP}$ remarca además el carácter doloso del tipo («a sabiendas»), esto es, el autor tiene plena conciencia de que está dictando una resolución con total apartamiento del derecho. La injusticia y la arbitrariedad en la que incurre la resolución constituyen, por consiguiente, rasgos fundamentales a la hora de decantar cuándo estamos ante la comisión de un delito de prevaricación administrativa. La jurisprudencia penal suele ser bastante rotunda al respecto valiéndose del empleo de expresiones muy contundentes reveladoras de ese choque frontal con el ordenamiento jurídico: resolución que se presenta como "contradicción patente, notoria e incuestionable con el ordenamiento jurídico»; resolución cuyo ajuste a la legalidad no es «sostenible mediante ningún método aceptable de interpretación jurídica»; o, en suma, resolución «falta de una fundamentación jurídica razonable distinta de la voluntad de su autor». En alguna ocasión, el Tribunal Supremo ha apelado incluso a la «cultura general» como crisol mediante el que cualquier persona, aunque carezca de especiales conocimientos jurídicos, puede constatar por sí misma la existencia de una resolución administrativa arbitraria e injusta ${ }^{28}$. La falta absoluta de competencia en la autoridad o funcionario que dicta la resolución; la

vado por la redacción primitiva de la Ley 30/1992, que, como se recordará, consideraba actos presuntos tanto a los que se producían en virtud del silencio positivo como a los que resultaban de un silencio negativo, que podían ser considerados como una desestimación presunta, esto es, como un acto administrativo denegatorio. Sin embargo, tal situación, según nos consta, cambió radicalmente con la modificación de la Ley 30/1992 operada por la Ley 4/1999, de 13 de enero (y que sustancialmente sigue en este punto la Ley 39/2015, de 1 de octubre), puesto que, a partir de ese momento, sólo el silencio positivo provocaba un verdadero y genuino acto administrativo, quedando relegado, en cambio, el silencio negativo a una mera ficción de acto que abre las vías del recurso administrativo y/o jurisdiccional. Por tanto, esta matización es importante, en la medida en que el silencio negativo ya no es expresión de una resolución denegatoria y no podría hacer los efectos de ésta a la hora de constituir una comisión omisiva del delito de prevaricación. Incluso antes de que se operase la modificación legislativa de la Ley 30/1992, esta conclusión era también la mantenida por algunos penalistas como GONZÁLEZ CUSSAC, J. L. (1997): El delito de prevaricación de autoridades y funcionarios públicos, 2. ${ }^{a}$ ed., Valencia: Tirant lo Blanch, quien, en contra de lo sostenido por otro sector de la doctrina penal (OCTAVIO DE TOLEDO, MORALES PRATS y RODRÍGUEZ PUERTA, entre otros), entendió que ni el silencio positivo, ni el negativo podían servir de base para una incriminación por delito de prevaricación administrativa. El silencio negativo porque «es una ficción procesal para facultar el acceso a la vía judicial y a la vía revisora de la propia Administración, pero nunca resuelve, siempre se recurre contra la presunta denegación» (pág. 87). Y el silencio positivo, porque «nunca puede crear derechos contrarios a la ley o inexistentes» (ibídem). De modo que, concluye GONZÁLEZ CUSSAC, «resolución expresa se contrapone a resolución presunta. Es decir, para evitar la paralización de la función pública se presupone una resolución, pero ésta no existe todavía, es una mera hipótesis, una ficción jurídica. Todavía no se ha decidido en un sentido o en otro, de ahí que no se exonere a la Administración de resolver expresamente (...) Y desde luego no parece aconsejable castigar penalmente una conducta con el solo apoyo de una ficción (...) Castigar por una resolución presunta, además de inadmisible en un Derecho Penal actual, sería prácticamente imposible: piénsese, por ejemplo, en la masificación de determinadas Administraciones Públicas» (pág. 89).

${ }_{27}$ El Auto del TS de 10 de abril de 2018, Sala 2. ${ }^{\text {a }}$,rec. cas. 20573/2017, Ponente: Berdugo Gómez de la Torre, ECLI: ES: TS: 2018: 3708A, citado en texto, además de relatar toda la doctrina jurisprudencial sobre la comisión por omisión del delito de prevaricación administrativa, hace relación de algunos ejemplos en que las sentencias del TS han admitido su existencia: Alcalde que no convoca Pleno para debatir una moción de censura; Alcalde que, por enemistad con un vecino, se niega a darle el certificado de empadronamiento solicitado por éste; Alcalde que se niega a convocar una comisión de investigación y darle datos a un concejal. Sin embargo, en el caso contemplado por el referido Auto, no se advierte prevaricación en la actitud del Alcalde que se negaba sistemáticamente a las peticiones del Interventor de dotar de mayores medios materiales y técnicos a los servicios de auditoría. Sí existe, en cambio, prevaricación administrativa, para la SAP de Palencia 41/2000, de 12 de junio, rec. apelación 44/2000, Ponente: Coullaut Ariño, en la negativa a otorgar escritura pública por parte de la Alcaldesa, negativa basada en errores banales y opiniones no formalizadas de algunos asesores y particulares que le expresan que el expediente de enajenación es nulo. Para el órgano jurisdiccional, hay que estar a la presunción de validez del acto de enajenación, presunción que no ha sido desvirtuada por la estimación de recurso alguno y que, en consecuencia, obliga a la práctica de la correspondiente escritura pública.

Sí es posible apreciar también comisión por omisión de delito de prevaricación administrativa en aquellos casos de disciplina urbanística en los que, apreciada por los servicios de inspección una situación de irregularidad urbanística (realización obra sin licencia o realización de obra que conculca manifiestamente los términos de la licencia otorgada), no se decreta inmediatamente la suspensión cautelar de las mismas por parte del Alcalde; inactividad con la que contribuye a la consolidación de derechos (STS 82/2017, de 13 de febrero, Sala 2. ${ }^{a}$, rec. cas. 729/2016, Ponente: Conde-Pumpido Tourón).

28 STS 257/2005, de 28 de febrero, Sala 2. ${ }^{a}$, rec. cas, 1304/2004, Ponente: Andrés Ibáñez. En esta sentencia de lo que se trataba es de un delito de prevaricación continuada del Director de Un Concello, quien en régimen de dedicación no exclusiva, propuso al Pleno la aprobación de una Base de Ejecución presupuestaria mediante la cual pasaba a cobrar 15.000 pesetas/diarias por concepto de asistencia al Ayuntamiento y a las Comisiones, o sea todos los días del mes. Señala en este sentido el TS que «los datos relativos a retribuciones, según la categoría de la dedicación, son, puede decirse, de cultura general, tratándose de personas instruidas que tengan alguna relación, en este caso, con la Administración Local. Y, en segundo término, porque es imposible que el acusado, como 
carencia en el acto de los requisitos formales indispensables a su propio contenido sustancial ${ }^{29}$; la omisión del procedimiento legalmente establecido o la falta de respeto a las normas esenciales del mismo constituyen, según la jurisprudencia penal, indicios que, cuando se siguen «a sabiendas» de que se está dictando una resolución con total apartamiento del derecho, dan lugar a la realización del delito de prevaricación administrativa ${ }^{30}$.

VII. Los rasgos diferenciadores de la desviación de poder y del delito de prevaricación administrativa parecen, por tanto, nítidos y sus consecuencias jurídicas en materia de invalidez son, como también nos consta, muy diferentes. Sin embargo, ya anticipamos que no es infrecuente que, en ocasiones, ambas instituciones se entrecrucen, dando lugar a resultados tan aparentemente contradictorios como que en el ámbito contencioso-administrativo se anule el acto por desviación de poder, y que posteriormente, la jurisdicción penal condene a los autores de la resolución anulada por prevaricación administrativa. Esta aparente antinomia puede derivar bien de la receptividad que el juez contencioso-administrativa muestre a la hora de suspender el proceso contencioso-administrativo para suscitar una cuestión prejudicial penal de carácter devolutivo; bien de que los hechos castigados como delito de prevaricación no guarden en realidad incidencia directa y decisiva con el objeto del proceso contencioso-administrativo, haciendo, por tanto, completamente innecesario que el juez contencioso-administrativo paralice aquel proceso para esperar un pronunciamiento al respecto de la jurisdicción penal.

Esto último es lo que acontece, por ejemplo, en el caso examinado por la Sentencia de la Sala de lo Contencioso-Administrativo del TSJ de Cataluña, núm. 129/2000, de 11 de febrero. La Alcaldesa de un municipio catalán había firmado directamente un contrato laboral para cubrir la plaza de Gerente. Celebradas elecciones municipales, la nueva Corporación nacida de las urnas modifica la relación de puestos de trabajo y declara lesivo el contrato, postulando la anulación de éste ante la jurisdicción contencioso-administrativa, pretensión que es desestimada por el TSJ, puesto que, según éste, lo que se tenía que haber declarado lesivo debió ser el acuerdo que autorizaba la firma del contrato, pero no éste (que es una simple ejecución de aquél). Sin embargo, no es esto último lo que ahora nos interesa, sino la rotundidad con la que el TSJ deniega la solicitud de que se plantee una prejudicial penal, pese a que el otorgamiento del contrato se hizo -según la Corporación municipal recurrente- incurriendo la Alcaldesa otorgante en un delito de prevaricación administrativa:

«....al respecto ha de señalarse que el propio art. 10.2 LOPJ priva de efecto suspensivo cuando se puede prescindir de la cuestión prejudicial penal para la debida decisión (o no condiciona directamente su contenido) del asunto que se plantea en otro orden jurisdiccional (en este caso, el contencioso-administrativo) y ello es lo que ocurre en el presente caso, ya que la eventual condena penal por prevaricación de la Alcaldesa supondría, de un lado, que la sentencia penal contendría un juicio de ilegalidad jurídico-administrativa del acto para el solo efecto de la represión, según dispone el art. 3 de la LECrim, juicio que carecería de fuerza de cosa juzgada ante los Tribunales contencioso-administrativos, y de otro, un pronunciamiento añadido sobre la concurrencia de dolo específico para la comisión de ese delito».

\footnotetext{
cualquier aspirante a la Dirección, antes de plantearse esta opicón, no hubiese realizado un estudio -por demás fácil- de las posibles alternativas en materia de retribuciones para saber a qué atenerse. Materia en la que, como demuestra el grado de sofisticación de Ios acuerdos obtenidos del Pleno, ha demostrado moverse con destreza y desde luego con interesada eficacia. Es por lo que a tenor de estas circunstancias, la ausencia de objeciones de parte de los sucesivos secretarios y de la Consejería no pueden tener el efecto neutralizador o sanatorio de la objetividad de la injusticia que pretende el recurrente».

${ }^{29}$ SAP de Asturias 271/1998, de 21 de mayo, proc. Abreviado 40/96, Ponente: Donapetry Camacho.

30 No obstante, no siempre que existe falta de procedimiento o se sigue otro procedimiento, podemos hablar de la existencia de un delito de prevaricación, pues es necesario confrontar si se dan o no los otros rasgos que definen lo injusto y arbitrario. Por ejemplo, la STS 181/2012, de 15 de marzo, Sala 2. ${ }^{a}$, rec. cas. 672/2011, Ponente: Colmenero Menéndez de Luarca, ECLI: ES: TS: 2012: 1605, entiende que no hay falta de procedimiento a efectos penales cuando un Ayuntamiento ha seguido -sin omitir ninguno de sus trámites esenciales- el procedimiento de la permuta en lugar del de la enajenación, puesto que había decisiones jurisprudenciales y legislaciones de otras Comunidades Autónomas que avalaban la legitimidad de la permuta de cosa futura.

Por el contrario, existe, en cambio, falta de procedimiento en el supuesto contemplado por la STS 629/2013, de 19 de julio, Sala 2. ${ }^{a}$, rec. cas. 261/2013, Ponente: Andrés Ibáñez, ECLI: ES: TS: 2013: 4108: un grupo de vecinos había solicitado al Alcalde que se habilitasen zonas de aparcamiento en su barriada. Dictando simplemente un Bando (por tanto, sin pliego de condiciones, ni instrumento de parecida índole), que justifica en razones de urgencia (que no solo no quedan constatadas en el expediente, sino que además resultan desmentidas por actos posteriores), el Alcalde lanza una oferta de compra de terrenos para destinarlos a aquel fin, y, desoyendo los informes de la Arquitecta y del Secretario sobre el elevado coste económico de los mismos en relación con los precios de mercado, adquiere los terrenos del Sr. A, con quien además ya había establecido conversaciones iniciales antes de dictar el Bando.
} 
La incidencia directa y decisiva de la conducta prevaricadora sobre el objeto del proceso seguido ante la jurisdicción contencioso-administrativa es, por tanto, el factor determinante para que el Tribunal contencioso decida plantear o no una cuestión prejudicial penal de carácter devolutivo. Si se plantea y la jurisdicción penal aprecia la existencia del delito, no se producirán disonancias en cuanto a los resultados entre lo fallado por una y otra jurisdicción, ya que, en principio, el Tribunal Contencioso-administrativo declarará la nulidad del acto administrativo por ser constitutivo de delito o dictarse como consecuencia de él. Al margen de esta incidencia directa, ni siquiera el hecho que, por ejemplo, la Administración ejerza sus potestades disciplinarias para sancionar a uno y no a todos los funcionarios que cometen la misma infracción disciplinaria constituirá un factor determinante para plantear la prejudicial penal, ya que tal circunstancia carece completamente de relevancia a la hora de decidir sobre la legalidad de la sanción disciplinaria impuesta ${ }^{31}$.

Junto a este extremo, que, como hemos visto, tiene que ver con la relación de inferencia directa existente entre el objeto del proceso contencioso-administrativo y el delito de prevaricación administrativa declarable por la jurisdicción penal, se dan también casos en los que, aun habiendo claros indicios sobre la existencia de tal inferencia, el juez contencioso-administrativo opta por no plantear prejudicial penal y por resolver el procedimiento anulando el acto por desviación de poder. Un paradigma de tal proceder lo representa la STSJ de Castilla-La Mancha, Sala de lo Contencioso, núm. 82/2006, de 1 de junio: por los recurrentes se había alegado indistintamente prevaricación administrativa y desviación de poder en la actuación arbitraria del Alcalde que, al margen de lo previsto en las Bases de una Convocatoria de Oposiciones, sin ostentar -según éstas- competencia para ello, y sin seguir procedimiento alguno, anuló el primer ejercicio del proceso selectivo al contar con indicios de que uno o varios miembros de la comisión de selección podrían haber facilitado las preguntas a un concreto opositor. EI TSJ declara la nulidad del acto por falta de competencia del Alcalde, por carencia de procedimiento y ipor mediar desviación de poder en la actuación del Alcalde! ${ }^{32}$.

Lo más paradójico es que en ocasiones, el Tribunal Contencioso-Administrativo llega a reconocer incluso en que se está ante «un abuso de derecho y una manifiesta desviación de poder determinante de arbitrariedad y rayana, incluso, en la prevaricación» ${ }^{33}$. Pese a ello, no plantea cuestión prejudicial penal devolutiva, y anula el acto por desviación de poder, cierto que dándole efectos equiparables a los que se producen mediante la nulidad ${ }^{34}$. Ahora bien, si el Tribunal Contencioso-Administrativo tiene tan clara la concurrencia de un delito de prevaricación en el dictado del acto anulado, ¿porqué no suscita la correspondiente cuestión prejudicial penal para apreciar la nulidad del acto ex. art. 47.1 d) LPAC? ¿Es que, pese a poseer la desviación de poder y la prevaricación administrativa rasgos diferenciadores aparentemente tan nítidos, a la postre éstos se diluyen en la práctica y ambas figuras terminan por mistificarse?

Si se observan la desviación de poder y la prevaricación administrativa con algún detenimiento, se constata que, en principio, y de conformidad con los indicios que ha destacado la jurisprudencia penal, el acto prevaricador ofrece síntomas externos de invalidez que son constatables por cualquier aplicador del Derecho. La apelación, que en alguna sentencia penal se hace a que un hombre de cultura general y sin par-

31 Este es el caso analizado por la STSJ de Galicia, núm. 446/2010, de 21 de abril, Sala de lo Contencioso, rec. apelación 133/2009, Ponente: Fernández Dotu, ECLI: ES: TSJGAL: 2010: 3599, En ésta, un funcionario a quien se había sancionado disciplinariamente por incumplir la normativa de incompatibilidades pide al TSJ que suspenda el proceso contencioso-administrativo hasta tanto se resuelven las diligencias previas planteadas contra las autoridades autoras del acto recurrido a las que se les imputan uno o varios delitos de prevaricación por omisión por no abrir expediente disciplinario a varios funcionarios que también están incumpliendo la citada normativa, «extremo éste que (según el TSJ), de prosperar, en nada afectaría, ni indirectamente a la cuestión que se debate en el presente pleito que versa sobre una concreta sanción impuesta al recurrente».

32 También sucede así en la SJCA núm. 6 de Bilbao, núm. 62/2013, de 24 de mayo, rec. 150/2012, Ponente: Martínez Navas, ECLI: ES: JCA: 2013: 777. El recurrente impugna una serie de comisiones de servicio que se habían dado a una ertzainza para que estuviese bajo la jefatura de su esposo y obtuviese ventajas económicas. Alega conjuntamente prevaricación administrativa y desviación de poder. El Juzgado anula por esta última, aunque dándole a la anulabilidad efectos muy semejantes a la nulidad, ya que condena a la ertzainza beneficiada por las comisiones de servicio anuladas a devolver todos los haberes percibidos en razón de su irregular situación administrativa.

33 STSJ de Galicia, núm. 90/2018, de 28 de febrero, Sala de lo Contencioso, rec. 286/2017, Ponente: López González, ECLI: ES: TSJGAL: 2018: 789.

34 «Por más que la Administración sanitaria trate desesperadamente, en su escrito de apelación, de tergiversar la contrastada realidad de los hechos reseñados, no logra su torticero propósito. Más aún, con esa aviesa actitud, lo que hace es reafirmar la convicción judicial que, ya en la instancia, llevó a la Juzgadora a quo a apreciar la existencia de una clara desviación de poder. La tesis de la parte demandada de que la reincorporación de la titular de la plaza determina el cese anticipado de quien le sustituye en la misma, resultaría acogible si no fuese porque aquella no se reincorpora voluntariamente, sino forzada por la Administración con el objeto de impedir, por esa anómala vía, la continuación de la sustitución (...) Y tal actuación por parte del SERGAS implica una evidente y censurable fraude de ley en cuanto se ampara en el texto de una norma para alcanzar un fin contrario al ordenamiento jurídico, un abuso de derecho y una manifiesta desviación de poder determinante de arbitrariedad y rayana incluso en la prevaricación». 
ticulares conocimientos jurídicos puede constatar fácilmente la existencia de una conducta prevaricadora, denota cómo el acto administrativo incurso en prevaricación busca de propósito un resultado injusto y arbitrario, tan grosera y palmariamente contrario a Derecho que su consecución hiere los sentidos de cualquier ciudadano medio. Además, este resultado injusto - que constituye el dolo específico propio de la comisión de este delito- se hace acompañar, al igual que las enfermedades, de indicios, que son, en realidad, síntomas externos que nos dan noticia y advierten sobre la magnitud del torcimiento del Derecho que el acto administrativo persigue: en unos casos, quien dicta la resolución carece de competencia para dictarla; otras veces, el acto se dicta sin seguir procedimiento alguno o siguiendo unos trámites que solo pueden calificarse como esperpentos del procedimiento que debiera haberse seguido, etc.

Frente a ello, la enfermedad que padece el acto administrativo incurso en desviación de poder es más recóndita, puesto que no ofrece síntomas externos. Externamente, quien lo dicta tiene competencia; se ha seguido el procedimiento marcado legalmente; e, incluso, en ocasiones, el fin nuevo que se busca para el acto dictado no es intrínsecamente injusto desde un punto de vista substantivo. Es verdad que es contrario a Derecho en la medida en que tuerce o desvía la finalidad típica de una potestad para hacerle desempeñar otra distinta. Otra distinta que, como sabemos, no necesariamente se dirige a la satisfacción de un interés privado, sino a la preservación de un interés público, en muchos casos carente hic en nunc de otro instrumentos o técnicas capaces de preservarlo ${ }^{35}$. Por ello, para juzgar la desviación de poder no podemos quedarnos en los síntomas o en los análisis externos del acto en cuestión, sino que hay que penetrar en sus interna corporis para verificar, a través de su motivación y de los datos contenidos en el propio expediente, la finalidad con la que el acto se dictó ${ }^{36}$. Una finalidad, que insisto, no tiene porqué buscar necesariamente el logro de un interés privado ni de un interés injusto o arbitrario, sino que puede ser el logro de otro interés público a costa de forzar o de torcer la finalidad típica de la potestad administrativa que sirve de cobertura al acto dictado.

Desviación de poder y prevaricación administrativa mantienen, por tanto, diferencias sustanciales entre ellas; diferencias que justifican el distinto tratamiento que el ordenamiento jurídico dispensa a una y otra. Por tanto, la aproximación o mistificación entre ambas figuras sólo podría producirse con respecto a aquellos casos en que el chequeo de los interna corporis del acto dictado por la Administración pusiese de manifiesto que, pese a la normalidad exterior del acto, e incluso pese a su ajuste formal a la legalidad substantiva, el objetivo perseguido al dictarlo no ha sido otro que el de alcanzar un resultado arbitrario e injusto en contradicción patente, notoria e incuestionable con el ordenamiento jurídico y sin que resulte posible efectuar una hermenéutica mínimamente razonable que permita descifrar una voluntad distinta de la nuda arbitrariedad de su autor ${ }^{37}$. Muy frecuentemente, estaremos ante uno de estos supuestos cuando la potestad se use para alcanzar un fin privado que resulte manifiestamente irreconciliable e incompatible con el interés público ${ }^{38}$.

35 Podrían traerse aquí a colación los célebres casos en los que ante la falta de previsión expresión en la legislación de orden público, los entonces Gobernadores Civiles utilizaron las potestades derivadas del Código de Circulación para sancionar las «tractoradas» auspiciadas por los agricultores [sobre este caso, véase LÓPEZ BENÍTEZ, M. (2017): Derecho Administrativo. Conceptos fundamentales, fuentes y organización (dir. por M. Rebollo Puig y D. Vera Jurado y coordinado por M. Rebollo Puig), 3. ${ }^{a}$ ed. Madrid: Tecnos, pág. 158]. Como dijo al respecto la STS de 11 de febrero de 1993, Sala 3. a, rec. 9731/1990, Ponente: Sánchez Andrade y Sal, «la Administración ha utilizado la potestad sancionadora de que le inviste el Código de la Circulación para fines ajenos a los que dicho texto protege, imponiendo las multas recurridas a unos hechos que constituían expresión del derecho de manifestación. En razón de ello, las multas impuestas conforme al Real Decreto 142/1978 que son objeto del presente proceso, no corresponden a los hechos sancionados, que -debemos repetirlo- constituían expresión del derecho de manifestación, y, en su caso, debieron ser castigados aplicando la legislación de orden público. Esta falta de relación directa entre la norma en que las sanciones se basan (el Código de la Circulación) y los hechos sancionados y el consiguiente uso indebido que la Administración ha hecho de su potestad sancionadora, determinan la nulidad de tales sanciones, y, por consecuencia, de los acuerdos en cuya virtud se impusieron, como ha declarado la sentencia impugnada, por lo que, en definitiva, procede desestimar el recurso de apelación interpuesto por el señor Abogado del Estado» (después, ha reproducido esta doctrina la STSJ de Galicia 188/2002, de 1 de febrero, rec. 6627/1998).

36 Creo que expresa muy bien esta idea FERNÁNDEZ FARRERES, G. (2018): Sistema de Derecho Administrativo, I, 4 . $^{a}$ ed., Madrid: Thomson-Civitas, pág. 637 en la definición que proporciona de desviación de poder: «La desviación de poder debe intervenir de forma subsidiaria para hacer frente a actos administrativos exteriormente acordes con las reglas de competencia y de procedimiento, e, incluso, con las del derecho material aplicado, pero que internamente supone una contravención del sentido teleológico de la actividad administrativa desarrollada».

37 El ATS de 29 de enero de 2016, Sala de lo Penal, causa especial 20810/2015, Ponente: Maza Martín, ECLI: ES: TS: 2016: 515A, considera precisamente que la firma por parte de un Senador de una serie de anuncios de colaboración con distintos medios de comunicación sin atenerse a la legislación de contratos no puede entenderse como desviación delictiva del ordenamiento jurídico al existir discrepancias interpretativas acerca de la naturaleza jurídica de estos convenios.

38 Pensemos, por ejemplo, que, al amparo del art. $137.4 \mathrm{~g}$ ) de la Ley de Patrimonio de las Administraciones Públicas, un Ayuntamiento decidiese poner fin a la situación de condominio que tiene con un propietario privado sobre una finca, vendiendo a este último su 
Incompatibilidad manifiesta con el interés público que podría verificarse asimismo en relación con aquellos supuestos en que el interés público perseguido por el acto dictado no solo es distinto del típico, propio de la potestad administrativa concernida, sino que en sus resultados se aproxima a la prevaricación administrativa en que el interés público alcanzado, pero no querido por la potestad ejercida, se logra a costa de enmascarar mediante dicho acto los mimbres y elementos de otro u otros actos que serían los que, en puridad, servirían para conseguir la decisión arbitraria e injusta realmente perseguida. Por ello, con respecto a estos últimos supuestos, no es infrecuente que en el acto aparentemente incurso en desviación de poder afloren algunos de aquellos síntomas externos que singularizan el delito de prevaricación, bien porque con el mismo se anticipe la arbitrariedad que posteriormente se completará a través de otro acto y del que el acto dictado supone una preparación ${ }^{39}$; bien porque se trate de evitar -en claro fraude de Ley- la consecución de ciertos derechos o ventajas reconocidas legalmente a los administrados ${ }^{40}$. Unimos a ello, en línea con quienes admiten que la desviación de poder pueda producirse con ocasión también de omisiones administrativas con respecto al deber de resolver que tiene en todo caso la Administración, la posibilidad de que esta modalidad de desviación de poder se tornase en prevaricación administrativa cuando la falta de respuesta administrativa a las solicitudes instadas, se integrase dentro de un plan preconcebido por las autoridades o funcionarios, a quienes competería resolver, para impedir que el administrado opte a los beneficios o ventajas que pudieran proporcionarle otro acto administrativo del que aquél constituye presupuesto necesario.

Ahora bien, en estos casos reseñados en los que el entrecruzamiento entre la desviación de poder y la prevaricación administrativa son tan intensos, lo que el juez contencioso-administrativo debe dilucidar es si, por la incidencia que tales conductas tengan sobre el objeto principal del proceso contencioso que ante él este suscitado, se dan o no los presupuestos legales necesarios para el pertinente planteamiento de la cuestión prejudicial devolutiva de cara a que el juez penal esclarezca si hay o no delito de prevaricación. Dándose tales circunstancias, resolver el proceso contencioso-administrativo sobre la base de la desviación de poder contribuye poco a la delimitación de esta figura con respecto a la del delito de prevaricación administrativa ${ }^{41}$.

cuota proindiviso. Externamente, el acto de enajenación es impecable jurídicamente: hay competencia para hacerlo y el procedimiento de adjudicación directa seguido está permitido por la Ley para tales casos. Sin embargo, el análisis de los interna corporis del acto de enajenación pone de relieve que ni existía un interés público que justificase la enajenación (puesto que incluso los frutos que, en razón de su participación, percibía la Administración eran cuantiosos), ni la finalidad perseguida era asumible jurídicamente, ya que la situación de condominio se daba con un familiar del Alcalde, que de esta forma se hacía con la plena propiedad de la finca y se veía favorecido además con una recalificación urbanística que el Ayuntamiento había auspiciado sobre dichos terrenos.

39 Como el caso contemplado por la STSJPV, núm. 201/2015, de 22 de abril, Sala de lo Contencioso, rec. Apelación 570/2013, Ponente: Alberdi Larizgoitia, ECLI: ES: TSJPV: 2015: 1182. En la litis, la Orden recurrida de 24 de septiembre de 2010 , mediante la que se dispone el cese del recurrente como secretario de alto cargo, lo que pretende en realidad es anticipar-eliminando los derechos preferentes que el recurrente tendría- la previsión de la inmediata supresión del puesto de trabajo llevada a cabo mediante Decreto de 26 de octubre de 2010. Como señala el TSJ: «Pues bien, a juicio de la Sala, siendo el cese de fecha 24 de septiembre de 2010 y produciéndose la amortización del puesto por el Decreto 272/2010, de 26 de octubre (BOPV de 12-11-2010,) no cabe establecer la necesaria relación de causa efecto, tal y como postula la Administración, ya que establecerla con el único fundamento de que en el momento del cese ya se estaba estudiando la modificación de la RPT que contemplaba su supresión, y de que la supresión fuera adoptaba un mes más tarde, carece de rigor, toda vez que, si a tenor del art. 50.2 LFPV, es intrínseca al nombramiento por el sistema de libre designación, la discrecionalidad del cese, nada impedía el cese adoptado el 24 de septiembre de 2010, y no cabe presumir que su verdadero fundamento fuera la necesidad de amortizar el puesto, ya que ello entraña presumir la mala fe de quien lo adoptó, atribuyéndole sin razón válida alguna la voluntad de impedir que el funcionario así cesado tuviera el derecho preferente del art. 51.2. LFPV, lo que raya no ya en la desviación de poder sino en la prevaricación, y ello sin aportar una prueba de suficiente entidad que lo acredite, más allá de la proximidad en el tiempo de la supresión de puesto».

40 Un ejemplo al respecto nos lo suministra la antes citada STSJ de Galicia 90/2018, de 28 de febrero. En ella, el TSJ, desestimando el recurso de apelación planteado por la Administración, confirma la decisión del Juez contencioso, que había estimado el recurso presentado por D. a Ariadna contra la Resolución del Servicio Gallego de Salud por la que se acordaba el cese de la actora en la plaza que venía cubriendo mediante contrato de sustitución. Dicho contrato de sustitución, que tenía efectos desde el día 1 de agosto de 2016, lo era para sustituir a D. ${ }^{a}$ Maribel, la cual había solicitado una comisión de servicios concedida el 14 de julio de 2016 por un período de seis meses y a la que se incorporaría el 1 de septiembre de 2016, puesto que el mes de agosto lo disfrutaría de vacaciones. Sin embargo, a primeros de agosto, hallándose ya D. ${ }^{a}$ Ariadna cubriendo la sustitución y con el fin de que no pudiese continuar sustituyendo a D. ${ }^{a}$ Maribel cuando ésta se incorporase a su nuevo destino, se le obliga a D. ${ }^{a}$ Maribel a reincorporarse durante el mes de agosto difiriendo sus vacaciones para otro momento. Por consiguiente, mediante la resolución recurrida de 23 de agosto de 2016 se le notifica a D. ${ }^{a}$ Ariadna el cese anticipado en su contrato de sustitución.

41 Sin olvidar además que, conforme a lo previsto por el art. 40.1 LEC, hay una obligación legal al respecto, como destaca MORCILLO, J. (2007): Teoría y práctica..., cit., pág. 292; obligación afirmada por nuestra jurisprudencia, como el ATS de 22 de mayo de 1996, que la citada autora reproduce en nota 281: «...la apreciación de la existencia de una cuestión prejudicial penal es un problema de los denominados de orden público procesal, que tiene carácter imperativo o ineludible para el órgano jurisdiccional y que este debe estimar de oficio, aunque no haya sido alegada por las partes». 